\title{
LITERATURA
}

1. Bankovskis P. Ekologijas makdonalds vai bruninieku ordenis //Diena - SestDiena. 1995. - 12.aug.

2. Bërziña I. Ceḷā uz ekologisko kultūru //Vide. Nr.2. - 1991.

3. Bojārs J. Starptautiskās tiesības. - R.: Zvaigzne ABC, 1996.

4. Starptautiskā dabas aizsardzība //Atmoda Atpütai. - 1993. - 25.aug.

5. Greenpeace // Environmental Encyclopedia. N.Y., 1998.

6. Joseph M.Petulla. The World Book Encyclopedia. Vol. 8. - 10. 1994.

\section{SIVĒNU APSTAROŠANA AR ULTRAVIOLETAJIEM STARIEM}

\author{
I.ZIEMELIS, U.ILJNS,
}

Latvijas Lauksaimniecības Universitāte

Pētera 2-2, Jelgava, Latvija, LV - 3001

\author{
P.SAVČENKO, I.ZEMI,ANOJS, I.ILIIČOVS,
} Harkovas Valsts Lauksaimniecỉbas tehniskā universitāte

\section{Ievads}

Ultravioletajiem (UV) stariem ir liela nozime biologisko procesu norisē dzīvnieku organismā. Tie veicina veselības stāvokl̨a uzlabošanos un produkcijas pieaugumu. Dabiskos apstākļos UV starojuma avots ir saule. Trükstot saules gaismai, organisms aug un attistās nepilnīgi. Ja dzīvnieki nesaņem UV starojumu, tie biežāk slimo ar mazasinỉbu un rahītu, asinsvadu slimībām, pasliktinātu vielmaiņu. Organisms novājinās un kḷūst uzṇēmīgs pret citām slimībām. UV stari paaugstina dzìvnieku biologisko um imunologisko aktivitāti, veicina endokrino dziedzeru darbỉbu, pozitīi ietekmē centrālo nervu sistēmu, organisma funkcionālo stāvokli un vielmainu, barības izmantošanas pakāpi un raksturu. UV starojums paaugstina leikocītu fagocitāro aktivitāti, normē vitamīnu apmaiñas procesus, părvēršot $D$ provitamīnu $D$ vitamīnā. Tas savukärt veicina fosfora un kālija izmantošanu. D vitamīns veidojas dz̄ivnieka ādā. Ja šì vitamīna sintēze organismā nenotiek, tas jādod mākslīgi, kas izmaksā dārgi.

Sivēniem atrodoties telpās, saules starojuma nepieciešamību jākompensē, pielietojot mākslīgu UV apstarošanu. Tā sevišķi derīga un efektĩva rudens - ziemas periodā. Iekārtojot dzīvnieku apstarošanu ar UV stariem, ietaises ierīkošanas izdevumi atmaksājas jau pirmajā gadā. Konstatēts [1], ka apstarošanas rezultātā sivēnu dzivimasas pieaugums palielinās par $24 \%$, teļu svars - par $25 \%$, piena izslaukums - par $10 \%$, vistu dējība - par $25 \%$. Samazinās jauno dzīvnieku nobeigšanās gadījumu skaits, paaugstinās fosfora un kālija saturs skeletā, uzlabojas minerālvielu apmaina organismā.

Taču apstarošana pozitīvi iedarbojas tikai tad, ja tiek stingri ievērota optimālā apstarošanas ekspozīcija. Pie nepietiekošām ekspozīcijām apstarošana nedod vajadzīgo efektu, bet pārāk liela ekspozicija var novest pie negatīva rezultāta. Pētījumu rezultāti un praktiskā pieredze rāda, ka minimālā ekspozīcija, pie kuras sākas organisma reakcija, atkarīga no sivēna dzīvmasas un apmatojuma stāvokļa. Tā sastāda 20-60\% no tās ekspozīcijas lieluma (vērtības), pie kuras vērojams maksimālais produktivitātes pieaugums. Optimālās ekspozīcijas pārsniegšana par 30-50\% samazina biologisko 
efektu un negatīvi ietekmē cūku produktivitāti. Apstarošanas ekspozīcijas noteikšanu būtiski ietekmē cūku turēšanas tehnologija. Taču esošās ekspozīcijas noteikšanas metodikas bieži to nenem vērā. UV starojuma ekspozīcija, kuru saņem dzivnieki viena starotāja gājiena laikã virs dzīvniekiem, atkarīga no UV starojuma avota tipa, tã jaudas, augstuma virs dzīvniekiem, starotāja tehniskā raksturojama (armatūras - atstarotāja, kustības ātruma, dzīvnieku atrašanās attāluma no starotāja u.c.). Esošās ekspozīcijas aprēķina metodikas pieñem, $\mathrm{ka}$ apstarošanas seansa laikā dzivnieki atrodas tieši zem starotāja un ir nekustīgi. Tādi nosacijumi ir pareizi, apstarojot govis, teḷus, bullı̧us, kuri atrodas aizgaldos un ir piesieti. Taču sivēnmātēm un sivēniem, kuri brīvi pārvietojas aizgaldos, šãdu metodiku izmantot nevar.

Daudzie autoru pētījumi xāda, ka apstarošanas seansa laikā sivēni var atrasties dažādos stãvokḷos - gulēt, stāvēt vai haotiski staigāt pa aizgaldu. Stāvot cūku muguras augstums no grīdas ir 1,7-2,1 reizes lielāks nekā gulıt. Tāpēc arī sanemtais starojums (atkarībā no starotāja augstuma virs dzivniekiem) var mainīties $1,4 \mathrm{li} \mathrm{d} z$ 1,7 reizes.

Haotiski pārvietojoties pa aizgaldu, dzīvnieku attālums no starotāja nepärtraukti mainās. Piemēram, ja aizgalda izmēri ir $5 \times 6,5 \mathrm{~m}$, tad šis attālums var mainīties no $1,5-$ 3,0 līdz 4,1-4,8 m, bet saņemtais apstarojums mainās 2,75-8,8 reizes. Tāpēc bija nepieciešams izstrādāt tādu UV starojuma ekspozīijas noteikšanas metodiku, kura ievērtētu dzivnieka stāvokli un atrašanās attālumu no starotāja.

Kā zināms, sakarsēti ķ̣ermeni bez redzamās gaismas starojuma ar vi|̣̣u garumu $\lambda=0,38-0,70 \mu \mathrm{m}$ izstaro arī neredzamos UV starus ar vilnu garumu $\lambda=0,04-0,4 \mu \mathrm{m}$ un infrasarkanos starus ar vilņu garumu $\lambda=0,8-3,8 \mu \mathrm{m}$. No UV staru joslas lauksaimniecības vajadzỉbām izmanto starus ar viļnu garumu no $0,04 \mathrm{lid} \mathrm{dz} 0,4 \mu \mathrm{m}$. Apstarošana ar vilnnu garumu $\lambda=0,38-0,315 \mu \mathrm{m}$ izsauc iedeguma efektu. Ši starojuma bioloǵiskā aktivitāte ir zema. Apstarošai ar UV stariem vidēji garo viḷnu diapazonā $\lambda=0,315-0,28 \mu \mathrm{m}$ ir eritēma pretrahīta iedarbība. Šāda apstarošana optimāāās devās labvēlīgi iedarbojas uz dzīvnieku organismu. Tā pārvērš provitamīnu $D$ aktīvas iedarbības vitamīnā $D$. Apstarošanai ìso UV viḷụu diapazonā $(\lambda=0,28-0,2 \mu \mathrm{m})$ ir pretbaktēriju iedarbība, un to izmanto gaisa, ūdens, trauku u.c. sterilizäcijai. UV starojumam ar vilngu garumu zem $0,2 \mu \mathrm{m}$ ir jonizējošs efekts. Eritēmo starojumu raksturo ar kxītošās eritēmās plūsmas attiecību pret apstaroto laukumu (ex/m $/ \mathrm{m}^{2}$ vai m•er/ $\mathrm{m}^{2}$ ). UV starojuma efekts atkarīgs no apstarošanas ilguma un intensitätes. Sivēnus ieteicams apstarot ar eritēmām lampām katru dienu, sākot no 2-3 dienu vecuma. Rekomendējamā eritēmā apstarojuma deva zīdējiem sivēniem ir 20-25 mer $\cdot \mathrm{h} / \mathrm{m}^{2}$, atşķirtiem sivēniem $60-80 \mathrm{mer} \cdot \mathrm{h} / \mathrm{m}^{2}$, bet nobarojamām cūkām un grūsnām sivēnmātēm $70-90 \mathrm{mer} \cdot \mathrm{h} / \mathrm{m}^{2}[2]$.

\section{Starotāja pārvietošanās ātruma aprēḳins}

Diennakts apstarošanas ilgumu, ievērojot cūku ķermeņa stāvokli, var izteikt

$$
t_{i}=t_{i 1}+t_{i 2}
$$

kur $\quad t_{i}-i$-tā dzīvnieka diennakts apstarošanas ilgums, $h$;

$t_{i 1}, t_{i 2}$ - laiks, kurā dzīvnieki attiecīgi stāv un gul apstarotā laukuma robežās, h:

Ja dzivnieki haotiski pārvietojas aizgalda robežās, apstarošanas laiku var izteikt

$$
\mathrm{t}_{\mathrm{i}}=\sum_{\mathrm{i}=1}^{\mathrm{n}} \mathrm{t}_{\mathrm{in}}
$$

kur $t_{i n}{ }^{-i-t a ̄ ~ d z i ̄ n n i e k a ~ a t r a s ̌ a n a ̄ s ~ l a i k s ~ a i z g a l d a ~} n$-tajā vietā, $h$. 
Īpatnējo apstarošanas ekspozīciju nosaka kā īpatnējā starojuma reizinājumu ar apstarošanas laiku

$$
H_{i}=E_{i} \cdot t_{i},
$$

kur $\quad H_{i}-$ ippatnëjā apstarošanas ekspozīcija, mer.h/m $/ \mathrm{m}^{2}$;

$E_{i}$ - īpatnejjais starojums (intensitāte) i-tā dzivnieka atrašanas vietā, mer $/ \mathrm{m}^{2}$;

$t_{i}$ - $i-t a \bar{~} d z \bar{z} v n i e k a$ apstarošanas ilgums, $h$.

Dzīvniekus var apstarot gan ar stacionārām, gan pārvietojamām apstarošanas iekārtām. Tas atkarīgs no vietējiem apstākḷiem fermã. Ja ir tikai viens aizgalds vai to skaits neliels, lietderīgāk uzstādīt UV starotāju virs katra aizgalda un katru diennakti uz noteiktu laiku starotāju ieslēgt. Ja aizgaldu skaits lielāks, lietderīgi lietot apstarošanas iekārtu ar pārvietojamu starotāju.

Izmantojot pārvietojamu starotāju, var būt sekojoši gadījumi:

1) starotājs pārvietojas tieši virs aizgalda, kurā esošie dzīvnieki nepārvietojas;

2) dzīvnieki atrodas labajā vai kreisajā pusē no starotāja kustības līnijas;

3) dzīvnieki haotiski pārvietojas pa aizgaldu.

Aprēķinot apstarošanas ekspozīciju visiem gadījumiem, pieņemam sekojošus vienkāršojumus:

1) starotāja kustr̄bas ātrums vienmēēigs;

2) staru avotu uzskatam par punktveida;

3) staru plūsmas sadalījumam ir kosinusa raksturs;

4) apstarojums sadalās vienmērīgi pa dzīvnieka ķermeņa projekcijas laukumu.

Starojuma plūsma, kura krīt uz laukumu s tieši zem starotāja, kad $\alpha=0$ (1.att.)

$$
\Phi=\frac{I_{0} \cdot s}{h^{2}}
$$

kur $\quad \Phi$-starojuma plūsma, mer;

$s$ - apstarotais laukums, $\mathrm{m}^{2}$;

$I_{0}$ - starojuma stiprums pie $\alpha=0, \mathrm{mer} / \mathrm{sr}$;

$h$ - attālums no starotāja līdz apstarotajai virsmai, $\mathrm{m}$.

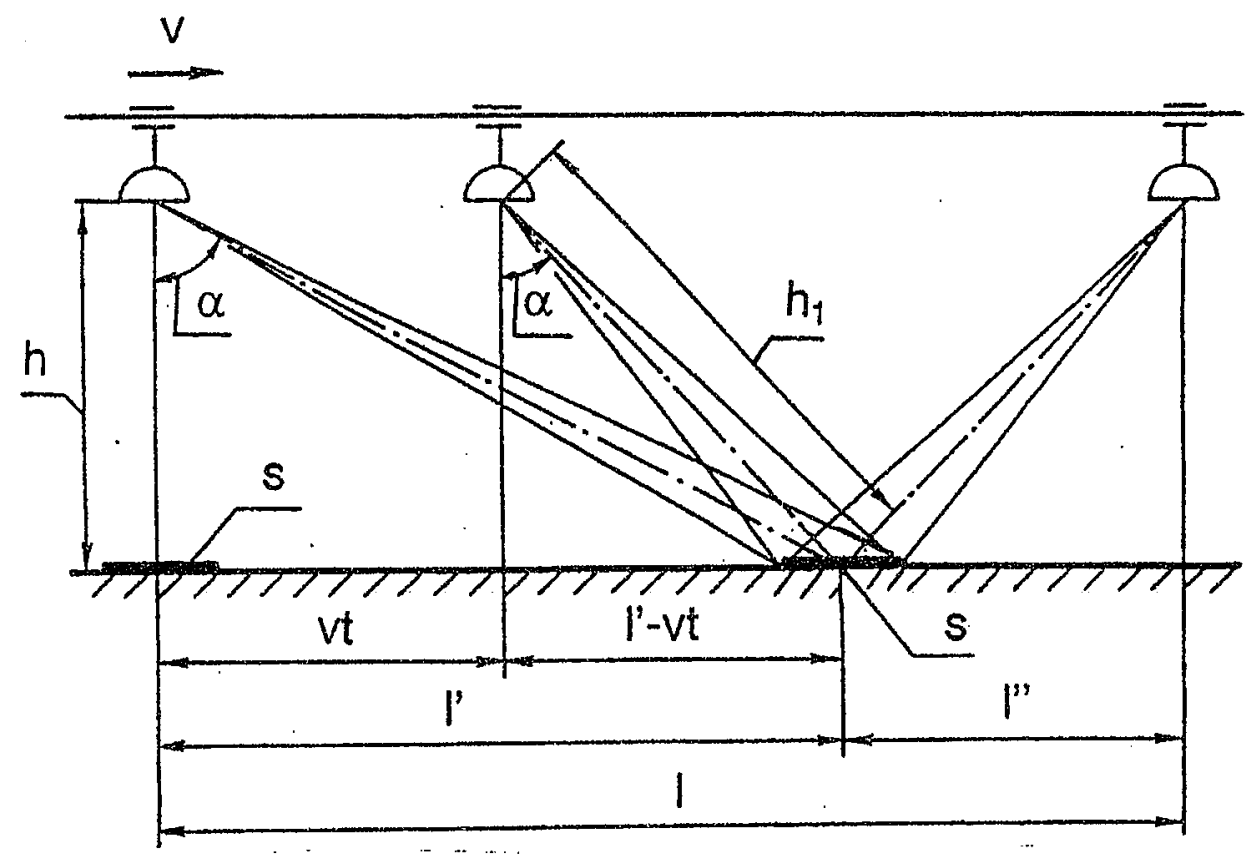

1. att. Apstarojuma aprēknina shēma: $l=l^{\prime}+l^{\prime \prime}$. 
Eritēmā starojuma plūsmas stiprums $I$ ir starojuma enerğijas plūsma $\Phi$ telpas leņķa $\omega$ vienībā

$$
I=\frac{\Phi}{\omega}
$$

kur $\quad \omega-$ telpas lenkis, kurā starojums sadalās, sr.

Pirmajā gadījumā, kad starotājs pārvietojas tieši virs dzīvniekiem, saskan̄ā ar kosinusa likumu uz laukuma vienỉbu krītošā eritēmā starojuma plūsmas stiprums

$$
I_{\alpha}=I_{0} \cdot \cos \alpha \text {, }
$$

kur $\quad I_{\alpha}$ - eritēmā starojuma plūsmas stiprums leņķa $\alpha$ virzienā, mer/sr;

$\alpha$ - leņkis starp starotäja vertikālo asi un liniju, kura savieno starotāja centru ar apstaroto elementāro laukumu, grad.

Ja $\alpha \neq 0$, tad uz laukumu s krītošā starojuma plūsma

$$
\Phi=\frac{I_{0} \cdot \cos ^{2} \alpha \cdot s}{h_{1}^{2}},
$$

kur $\quad h_{1}$-attālums no starotāja līdz laukumam $s, \mathrm{~m}$.

Lielumu $h_{1}^{2}$ var izteikt (1.att.)

$$
h_{1}^{2}=h^{2}+(1-v \cdot t)^{2},
$$

kur $\quad l$ - apstarotāja noietais celš̌ virs aizgalda, kura laikā dzīvnieks tiek apstarots vai kura laikā apstarojumu uzskaita, $\mathrm{m}$.

Saskanāa ar 1.att.

$$
h=h_{l} \cdot \cos \alpha ; \quad h^{2}=h_{l}^{2} \cdot \cos ^{2} \alpha ; \quad \text { un } \quad h_{l}^{2}=\frac{h^{2}}{\cos ^{2} \alpha} .
$$

No sakarỉbām (8) un (9) iegūstam, ka

$$
h^{2}+(t-v \cdot t)^{2}=\frac{h^{2}}{\cos ^{2} \alpha}
$$

un

$$
\cos ^{2} \alpha=\frac{h^{2}}{h^{2}+(l-v t)^{2}}
$$

Ievietojot formulas (8) un (11) izteiksmē (7), uz laukumu s krītošā starojuma plüsma būs

$$
\Phi=\frac{I_{0} \cdot h^{2} \cdot s}{\left[h^{2}+(l-v \cdot t)^{2}\right]^{2}}
$$

UV starojuma ekspozicija, kuru saņems dzīvnieki starotājam noejot ceļa gabalu $l$

$$
H=\int_{0}^{t} \frac{I_{0} h^{2} s}{\left[h^{2}+(l-v \cdot t)^{2}\right.} d t=\int_{0}^{t / \nu} \frac{I_{0} h^{2} s}{\left[h^{2}+(l-v \cdot t)^{2}\right]^{2}} d t
$$

Integrējot izteiksmi (13) iegūstam

$$
H=\frac{I_{0} s}{2 v}\left(\frac{l}{h^{2}+l^{2}}+\frac{1}{h} \operatorname{arctg} \frac{l}{h}\right)
$$

Cela garums $l$, kurā notiek laukuma $s$ apstarošana, atkarīgs no starotāja novietojuma augstuma virs grïdas un tā aizsarglenksa $\beta$ (2.att.):

no kurienes

$$
\operatorname{ctg} \beta=\frac{l}{2 h},
$$

$$
l=2 h \operatorname{ctg} \beta .
$$




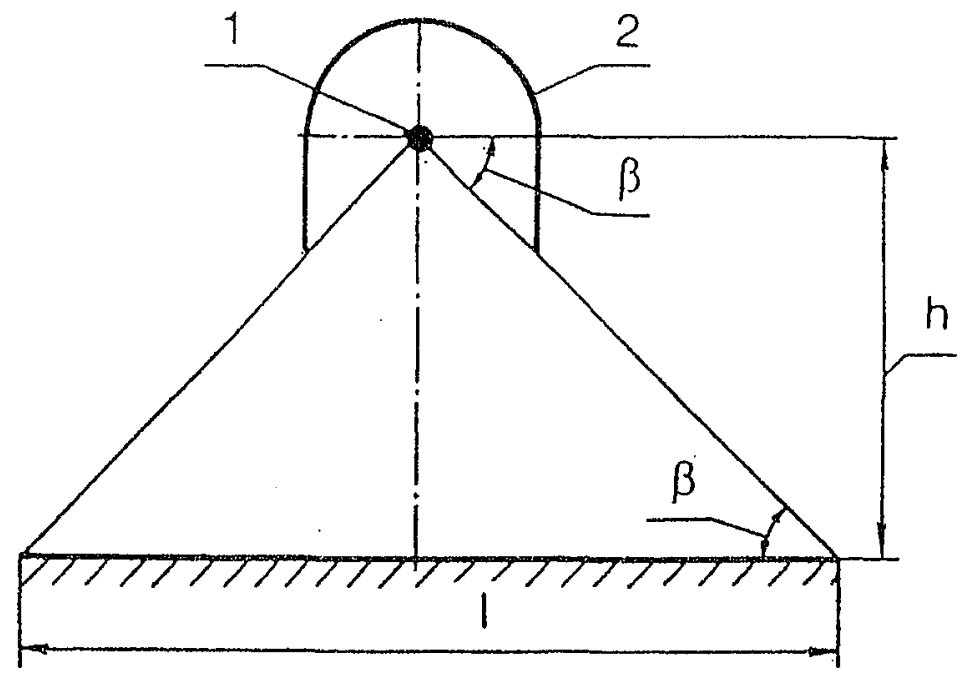

2. att. Apstarotā laukuma garuma aprēķina shēma:

1 - starotājs; 2 - atstarotājs; $h$ - novietojuma augstums, m;

$l$ - apstarotā laukuma garums, $m ; \beta$ - starotāja aizsargleņkisis.

Otrajā gadījumā, kad dzīvnieki atrodas attālumā $1_{n}$ no starotāja kustības trajektorijas projekcijas uz aizgalda grīdu (3.att.), eritēmā starojuma plüsmas aprēķina formulas izvedums, līdzìgs formulas (12) izvedumam.

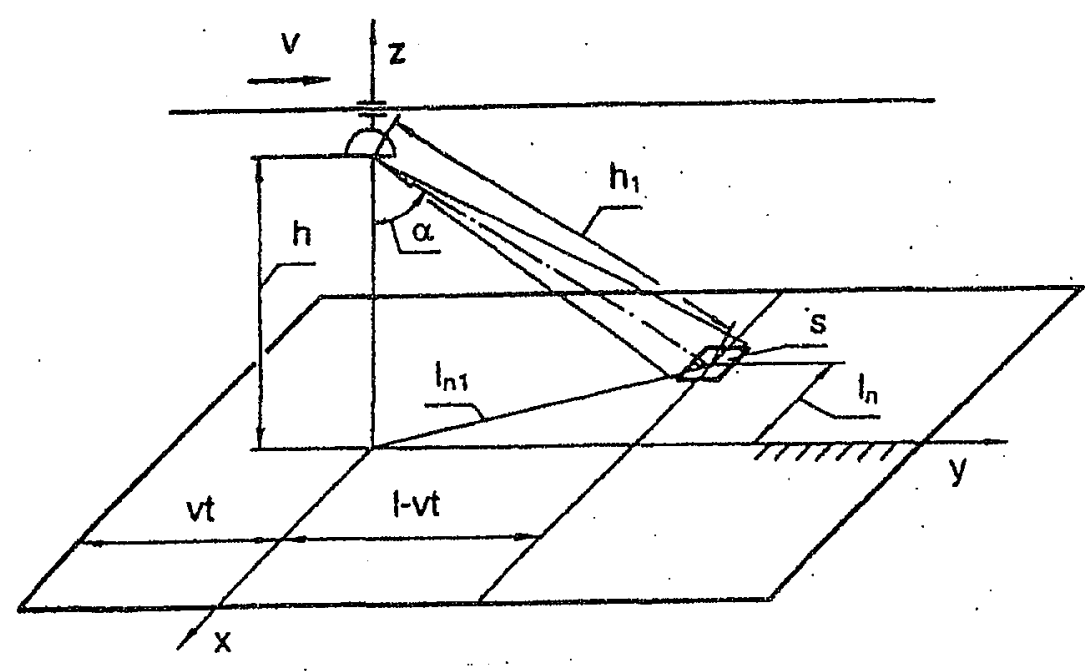

3. att. Aprēķina shēma: starotājs pārvietojas plaknē zy.

No 3.att. seko, ka

$$
\begin{aligned}
& h_{l}^{2}=h^{2}+l_{n_{l}}^{2}, \\
& l_{n_{I}}^{2}=l_{n}^{2}+(l-v \cdot t)^{2} . \\
& h_{l}^{2}=h^{2}+l_{n}^{2}+(l-v \cdot t)^{2} .
\end{aligned}
$$

No formulām (9) un (19)

$$
h_{l}^{2}=h^{2}+l_{n}^{2}+(l-v \cdot t)^{2}=\frac{h^{2}}{\cos ^{2} \alpha},
$$

no kurienes

$$
\cos ^{2} \alpha=\frac{h^{2}}{h^{2}+l_{n}^{2}+(l-v \cdot t)^{2}}
$$


Ievietojot sakarības (19) un (21) formulā (7), iegūstam izteiksmi uz laukumu s krītošā starojuma plüsmas aprēķinam

$$
\Phi=\frac{I_{0} \cdot h^{2} \cdot s}{\left[h^{2}+l_{n}^{2}+(l-v \cdot t)\right]^{2}} .
$$

UV starojuma ekspozīcija, kuru saṇems dzīvnieki, starotājam noejot ceļu $l$, būs:

$$
H=\int_{0}^{t} \frac{I_{0} \cdot h^{2} \cdot s}{\left[h^{2}+l_{n}^{2}+(l-v \cdot t)^{2}\right]^{2}} d t=\int_{0}^{l / v} \frac{I_{0} \cdot h^{2} \cdot s}{\left[h^{2}+l_{n}^{2}+(l-v \cdot t)^{2}\right]^{2}} d t .
$$

Integrējot šo izteiksmi, iegüstam formulu dzīvnieku saņemtā UV starojuma ekspozicijas aprëkinam, tiem atrodoties attālumā $l_{n}$ no starotāja kustības trajektorijas projekcijas uz küts grïdas:

$$
H=\frac{I_{0} \cdot h^{2} \cdot s}{2 v\left(h^{2}+l_{n}^{2}\right)}\left(\frac{l}{h^{2}+l_{n}^{2}+l^{2}}+\frac{1}{\sqrt{h^{2}+l_{n}^{2}}} \operatorname{arctg} \frac{l}{\sqrt{h^{2}+l_{n}^{2}}}\right) .
$$

Trešajā, vairāk vispārīgā gadj̄jumā (4.att.), ticamības varbūtību $f(x, y)$, ka dzīvnieki atradīsies punktā $\mathrm{C}$ ar koordinātēm $\mathrm{x}$ un y laika momentā $t$, iespējams aprakstīt ar t.s. Kolmogorova otro vienādojumu [3]:

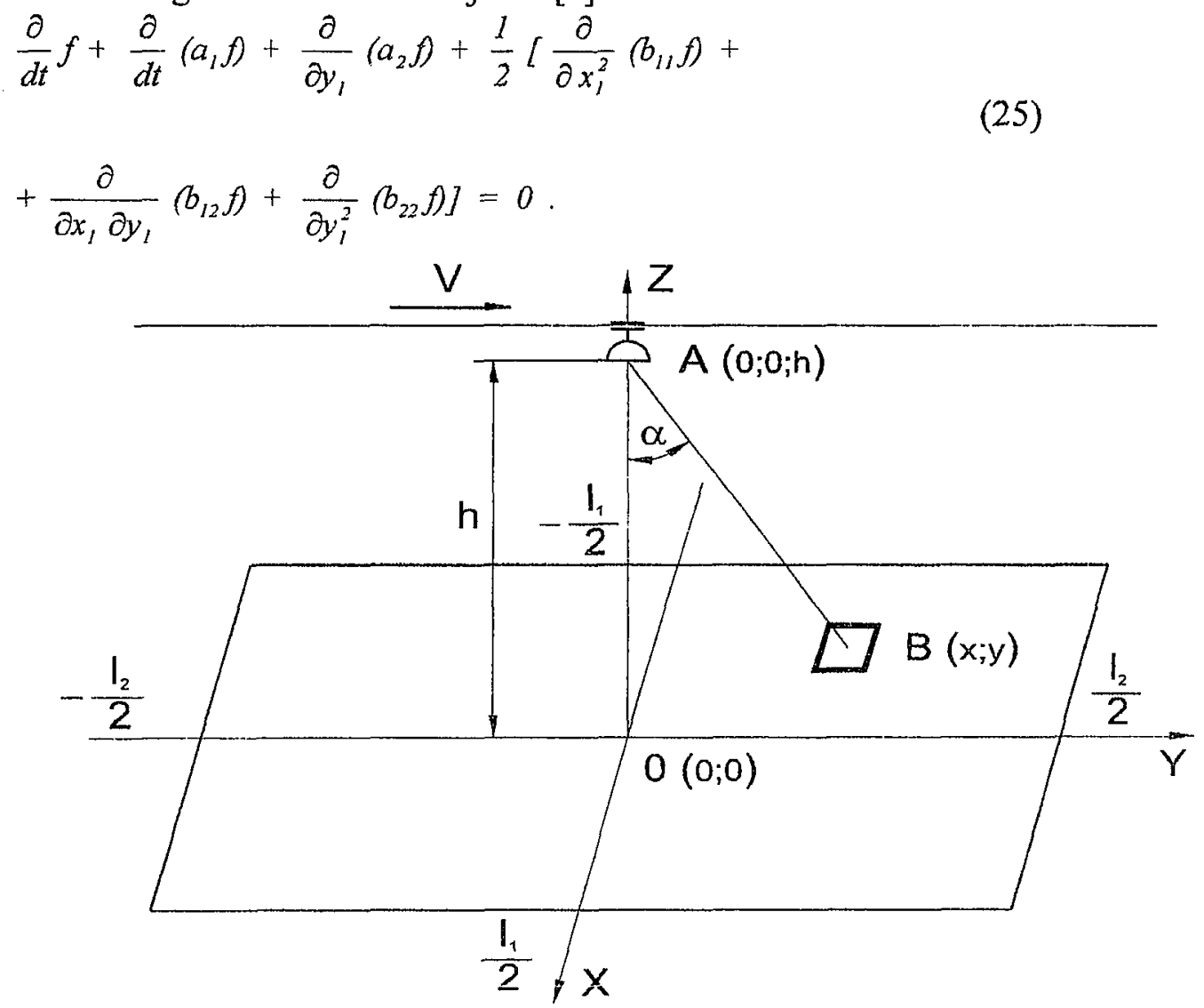

4.att. Apstarojuma aprēḳina shēma, ja sivēni pārvietojas pa aizgaldu.

Funkcijai $f$ jāapmierina sekojošas prasības:
a) $\int_{0}^{l_{1} / 2} \int_{0}^{2} f d x_{1} d y_{1}=1$;
b) $f>0$; 
nulli.

c) atvasinājums pa līniju, kura ierobežo apstaroto grīdas laukumu, vienāds ar

Vienādojumā (25), kurš apraksta apstarojamā objekta gadījuma (haotiskus) pārvietojumus, loceklis $b_{22}$ nav vienāds ar nulli, tā kā katrs no reizinātājiem ir atškirings no nulles. Tas tāpēc, ka apskatāmajā gadijumā sivēnu atrašanās dažādos punktos y ass virzienā ir vienādi iespējama un ir spēkā sakarība

$$
b_{22}=\frac{l_{0}}{\tau},
$$

kur $\quad l_{0}$ - elementārais pārvietojums, $\mathrm{m}$;

$\tau$ - laiks, kurā tiek izdarīts elementārais pārvietojums $l_{0}, \mathrm{~h}$.

Ticamības varbūtība, ka apstarojamais objekts (sivēns) $f$ atradīsies punktā ar koordinātēm $\mathrm{x}$ un y laika momentā $t$, tiek aprēķinăta pēc izteiksmes

$$
\begin{aligned}
& f=\frac{1}{l_{1} l_{2}} \sum_{n=\infty}^{\infty} \exp \left(-n^{2} \frac{t}{T_{I}}\right) \cdot \cos \frac{n \pi x}{l_{1}} \cdot \cos \frac{n \pi x_{0}}{l_{l}} x \\
& x \sum_{n=\infty}^{\infty} \exp \left(-m^{2} \frac{t}{T_{2}}\right) \cdot \cos \frac{m \pi y}{l_{2}} \cdot \cos \frac{m \pi y_{0}}{l_{2}},
\end{aligned}
$$

kur

$$
\begin{aligned}
& T_{1}=\frac{2}{\pi^{2}}\left(\frac{l_{1}}{l_{2}}\right)^{2} \tau ; \\
& T_{2}=\frac{2}{\pi^{2}}\left(\frac{l_{2}}{l_{0}}\right)^{2} \tau ;
\end{aligned}
$$

$I_{0}$ - apstarojamā objekta elementārais pārvietojums, $\mathrm{m}$;

$l_{1}$ - aizgalda platums, $\mathrm{m}$;

$l_{2}$ - aizgalda garums, $\mathrm{m}$;

$m, n$ - summēšanas indeksi;

$\mathrm{t}$ - tekošaịs laiks, $\mathrm{h}$.

Ja apstarošanas laiks t ievērojami lielāks par elementārā pārvietojuma laiku $\tau$, eksponentu kāpinātāji ir lieli negatīvi skait]i, bet paši eksponenciālie reizinātāji kḷūst ḷoti mazi. Kvalitatīvi tas nozīmē, ka apstarošanas laikã "objekts" pagūst daudzkārt pabūt visos apstarotā laukuma punktos (vietās).

Šajā gadījumā no attiecības

$$
H=\frac{I_{0} \cdot s}{2 v}\left(\frac{l}{h^{2}+l^{2}}+\frac{1}{h} \operatorname{arctg} \frac{l}{h}\right)
$$

un sakarības (27) seko 


$$
\begin{aligned}
& H=\frac{1}{l_{1} \cdot l_{2}} \cdot \frac{I_{0} \cdot h^{2} \cdot s}{2 v}\left\{\int_{-\frac{l_{2}}{2}}^{\frac{l_{2}}{2}} d x \int_{-\frac{l_{1}}{2}\left(h^{2}+y_{l}^{2}\right)\left[h^{2}+y_{1}^{2}+\left(\frac{l_{1}}{2}-x_{I}^{2}\right)\right]}^{\frac{l_{1}}{2}} d y+\right. \\
& \left.+\int_{-\frac{l_{2}}{2}}^{\frac{l_{2}}{2}} d x_{l} \int_{-\frac{l_{1}}{2}}^{\frac{l_{1}}{2}} \frac{1}{\left(h^{2}+y_{1}^{2}\right)^{\frac{3}{2}}} \operatorname{arctg} \frac{\frac{l_{2}}{2}-x_{I}}{\sqrt{h^{2}+y_{1}^{2}}} d y_{1}\right\} .
\end{aligned}
$$

Pārveidojot integrāḷus, iegūstam

$$
\begin{aligned}
& H=\frac{1}{l_{1} \cdot l_{2}} \cdot \frac{I_{0} \cdot h^{2} \cdot s}{2 v}\left[\frac{l_{2}}{2} \int_{-\frac{l_{1}}{2}}^{\frac{l_{1}}{2}} \frac{1}{\left(h^{2}+y_{l}^{2}\right)^{3 / 2}} \operatorname{arctg} \frac{l_{2}}{\sqrt{h^{2}+y_{l}^{2}}} d y+\right. \\
& \left.+\int_{-\frac{l_{1}}{2}}^{\frac{l_{1}}{2}} \frac{d y_{1}}{h^{2}+y_{l}^{2}}+\frac{l_{2}}{2} \int_{-\frac{l_{2}}{2}}^{\frac{l_{2}}{2}} \frac{d x_{1}}{\left(h^{2}+y_{l}^{2}\right)+\left(x_{1}-\frac{l_{2}}{2}\right)^{2}}\right] .
\end{aligned}
$$

Izpildot integrēšanu un izmantojot nosacījumu

$$
\frac{l_{2}}{\sqrt{h^{2}+\left(\frac{l_{1}}{2}\right)^{2}}}>1
$$

atrodam, ka

$$
H=\frac{\pi \cdot l_{0} \cdot h \cdot s}{l_{1} \cdot v} \cdot \frac{1}{\sqrt{l_{l}^{2}+h^{2}}} .
$$

Gadījumā, kad $l_{1} \gg h$, t.i. aizgalda platums lielāks par starotāja novietošanas augstumu, izteiksme (32) kḷūst

$$
H=\frac{\pi \cdot I_{0} \cdot s \cdot h}{l_{I}^{2} \cdot v}
$$

İegūtās izteiksmes dod iespēju aprēķināt apstarošanas ekspozīcijas lielumu atkarībā no apstarošanas iekārtas parametriem, aizgalda izmēriem un nepieciešamās diennakts apstarojuma normas. Pēc šĩs metodes bija aprēkinātas un izgatavotas vairākas pārvietojamās UV apstarošanas iekārtas. Pēc pārbaudēm laboratorijas apstākḷlos, kuras deva pozitivus rezultātus, tika veiktas šo iekārtu pārbaudes cūku kūtīs - ražošanas apstākḷıs. Vairākas iekārtas tika uzstādītas Harkovas rajona (Ukraina) cūku fermās, bet viena - Jelgavas raj. saimniecỉbas "Zaļenieki" cūku kompleksā "Dukāti" jaundzimušo sivēnu novietnē. Eksperimentālās pārbaudes ražošanas apstākļos parādīja, ka pārvietojamo UV apstarošanas iekārtu izmantošana paaugstina sivēnu dzīvmasas pieaugumu par $20-25 \%$, bet to saglabāšanu par $8-12 \%$ pie tã paša barošanas lìmeņa. 


\title{
Secinājumi
}

1. Sivēnu apstarošana ar UV stariem, ievērojot optimālās apstarošanas normas, veicina to veselības stāvoḳ̦a uzlabošanos, dzīvmasas pieaugumu un nobeigšanās gadijumu samazināšanos.

2. Aprēķinot pārvietojamās UV apstarošanas iekārtas, nepieciešams ņemt vērā, ka apstarošanas laikã sivēni var stāvēt, gulēt vai haotiski pārvietoties pa aizgaldu.

3. Formulas (4), (9) un (10) dod iespejju noteikt dzivnieku sanemto UV starojuma ekspozīcijas lielumu un otrādi - pēc uzdotās apstarojuma normas noteikt pārvietojamas apstarošanas iekārtas parametrus.

\section{LTTERATŨRA}

1. Filatkins P. Fermu elektroiekārtas. - R.: Zvaigzne, 1972. - 301 lpp.

2. Galeņins A., Kostruba S. Lauku elektriķa rokasgrāmata. - R.: Avots, 1984 - 237 lpp.

3. Свешкиков А.А. Прикладные методы случайных функций.- М.: Наука, 1968. $320 \mathrm{c}$.

\section{SUBDIVIDING OF THE TERRITORY OF" "EKRANAS" PLANT ACCORDING TO DANGEROUS POINT SUMMARY POLLUTION CODES}

\author{
RIMANTÉ ZINKUTE் \\ Institute of Geology, T.Ševčenkos 13,2600 , Vilnius, Lithuania
}

ABSTRACT. According to factor analysis results of topsoil geochemical data it can be seen that the pollution on extremely contaminated territory of "Ekranas" plant in Panevezys is polygenous. According to technogentty level four of the seven distinguished factors are technogenous: one of them $\mathrm{Mo}-\mathrm{Cr}-\mathrm{Mn}-\mathrm{Ni}-\mathrm{Cu}-\mathrm{W}-\mathrm{Sn}-\mathrm{Co}-\mathrm{Ag}$ is characteristic of metal processing enterprises, the second one $Y-C d-Z n-o f$ electrical engineering, partly - metal processing, the third $S b-P b-S r-B a-L i-U-A s$ one-of special (kinescopes) glass production, the fourth La-Ce one - of its polishing. These paragenetic associations were used for determination of dangerous point summary pollution codes and subdivision of the territory of "Ekranas" plant into zones according to them.

\section{Introduction}

Industrial enterprises are the main pollutants of the urbanised territories. Some of them are heavily contaminating not only their own territory but even the surrounding part of the town. According to Geochemical atlas of Panevéžys (1997) the enterprises of electrical engineering are among them. Their territories are centres of multielement pollution including not only common spectrum of elements-contaminants but often also complementary elements the content of which is usually below the detection limit of DC Arc Emission Spectrometry. Total summary contamination index $Z_{s}$ computed on the basis of recommended methodics (1987) including all main elements-contaminants 